\title{
Application of the technical - pedagogical resource 3D holographic LED-fan display in the classroom
}

\author{
Mauricio Xavier Prado Ortega ${ }^{1 *}$ D, Jorge Cristopher Delgado Ramírez ${ }^{2} \mathbb{D}$, Jorge Washington Valarezo Castro ${ }^{2}$, \\ Jorge Luis Armijos Carrión² (D), Asisclo Alfonso Ávila Carvajalº and Anyeline Natalia González Segarra ${ }^{3}$ (D)
}

\author{
* Correspondence: mprado@ \\ utmachala.edu.ec \\ ${ }^{1}$ Universidad Técnica de Machala, \\ Avenida Panamericana km 5.5 via a \\ Pasaje, Machala, Ecuador \\ Full list of author information is \\ available at the end of the article
}

\begin{abstract}
The currently secondary education needs the contribution of new technopedagogical resources, where the resource, teaching and learning skills are integrated to motivate students in their learning. For this reason, the field of holographics is presented as a dynamic alternative to the growing use of image projectors. However, these resources are not available to teachers and educational institutions because of their high costs. This research seeks to show how led-based technologies can be applied in secondary education, so allow the classroom attention of students and improve their interest in learning through the use of the 3D Holographic LED-Fan Display. In this way, the objective is to improve the student's motivation for learning using current resources according to the realities of the current context of education, which may not have availability of mobile devices due to their high costs, thus they have not been considered for the present study. The research approach is a mixed methodology combining qualitative and quantitative information through an educational study case applied to the Kléber Franco Cruz School with the intervention of pre-professional practices carried out by the Technical University of Machala in Ecuador, through the realization of an integrative knowledge project with students with different profiles according to their curriculum, in order to face the different challenges of teaching.
\end{abstract}

Keywords: Learning, Led technology, Pedagogy, 3D holograms, Education, Constructivism, Didactics

\section{Introduction}

Nowadays, technology is global and is growing fast, hence its close relationship with education in all areas and levels is something unavoidable. Currently, the influence of holographic resources is becoming more and more recurrent in educational institutions due to the ease of handling and the predisposition of students to learn. The title of this paper suggested a similarly exciting volume of collective topics. The lack of interest in the classes taught by the teachers and the absence of dynamic pedagogical resources do not help to motivate students' individual learning. Among some reviewed studies, it is necessary to highlight one: "Extending interest," it is established that the

(c) The Author(s). 2020 Open Access This article is licensed under a Creative Commons Attribution 4.0 International License, which permits use, sharing, adaptation, distribution and reproduction in any medium or format, as long as you give appropriate credit to the original author(s) and the source, provide a link to the Creative Commons licence, and indicate if changes were made. The images or other third party material in this article are included in the article's Creative Commons licence, unless indicated otherwise in a credit line to the material. If material is not included in the article's Creative Commons licence and your intended use is not permitted by statutory regulation or exceeds the permitted use, you will need to obtain permission directly from the copyright holder. To view a copy of this licence, visit http://creativecommons.org/licenses/by/4.0/. 
final component in the interest aspect is related to the design of activities which purpose is to catch/extend student's interest in the particular field after being immersive through the learning activity. Extending interest also predisposes students to reengage in similar activities which should rise the possibilities for new opportunities. Henceforth, this should be the right time where meaningfulness and self-directed learning enters into the field of an immersive learning process. The main intention is to assist the students in transforming their maintained situational interest into emergent individual interest (Wong et al., 2020).

It is important to take into consideration the problem of learning interests of high school students in Ecuador. For example, some authors state that: the outcome of science education should be students will develop the knowledge, skills, attitudes and values which will allow them to take a posture in a situation on scientific issues and at the same time, to solve problems they may face in the society they live. They should have developed an enquiring approach, awareness and skills that will allow them to find the answers to the problems. A key aim of science education should be to recognize the natural curiosity that young students bring to the process of exploring and understanding the natural world they live in. These attitudes must be valued and enhanced, ensuring these creative perspectives for being retained in a long term (Thanga Shyla, 2015a).

This document is structured in a study on the influence of holograms through the use of devices such as the 3D Holographic LED-Fan Display in the classroom to improve the interest of secondary students in learning content in their subjects. A case study was carried out through a research with an action methodology by the UTMACH, through experimental classes in which teachers and students from the Kléber Franco Cruz School participated. Among the most important results achieved are the ease of integrating holographic devices, the acceptance of students to interact with this technology, the increase of interest and motivation for topics and content using 3D Holographic LED-Fan.

\section{Research questions}

Through pre-professional classroom observation practices carried out at the Kléber Franco Cruz School by the students of the Experimental Sciences degree, various problems that affect the student's PEA were instantly detected, as the lack of interest in learning content related to the Biology course, so the following question arises:

How to strengthen the dynamics of the class by using the techno-pedagogical resource, 3D Holographic LED-Fan Display in the biology course of the third year of baccalaureate students of the Kléber Franco Cruz School?

The General objective is promoting the use of the 3D Holographic LED-Fan Display in the classroom as a techno-pedagogical resource, for the purpose of improving/reinforcing the dynamics of classes in the third year of baccalaureate's students of the Kléber Franco Cruz School. As Specific objectives we have:

1. Observe the academic performance of the students prior to the use of the technopedagogical resource 3D Holographic LED-Fan Display. 
2. Apply the techno-pedagogical resource 3D Holographic LED-Fan Display during the development of the class.

3. Evaluate the performance of the students after using the techno-pedagogical resource 3D Holographic LED-Fan Display.

It could reasonably be expected that students' teachers should strive to extend their skills beyond the didactic application of digital technologies, towards to acquire a more holistic view encompassing personal and social considerations, such as those introduced earlier. While this is would be a difficult challenge to undertake, it is an essential because if the students they teach are going to be better-prepared to productively act in increasingly digitally-mediated/personal and professional environments (Falloon, 2020).

\section{Theoretical background}

Holograms have been existing at least for the last two decades. The first person to invent this hologram is Dennis Gabor. Holograms look easy to implement, but in the real world, it is different. The implementation is much more complicated and is elaborated in the following sections (Ramachandiran, Chong and Subramanian, 2019).

Holography, is a 3D display technique that can display a natural 3D image close to an actual object and does not require scanning and synchronisation processing because it records and reconstructs light waves emitted from the object via light interference and diffraction. The interference between the light from the object and the reference light generates an interference fringe pattern called a hologram (Yamada, Kakue, Shimobaba and Ito, 2018). This class of tecnology brings promising possibilities in the field of education. It provides opportunities for authentic learning and engages learners in learning. The combination of the learning theories, learning techniques and multimedia elements are very important and provide effective elements as for students and teachers as well (Hayaati, Alwi and Wahab, 2017).

The process of technology's implementation has different stages depending on the approach that is followed (Mora Rodríguez, 2013). It is very clear as Girvan suggests in his study, any technology is an artefact within a wider milieu. "Therefore, a definition of a technology needs to take into account the activities and practices when using it, as well as the social arrangements and organizational forms surrounding its use. Each time we re-engage with a technology as part of our everyday social experience, we encounter it afresh, re-establishing and reformulating its use in terms of both function and functionality" (Girvan, 2018).

Naturally, for new technology to be accepted in a new environment, it is important to help teachers to include/adapt the technology to their lesson plans. For a new technology to be adopted by a school, significant planning, teacher training, and resources are needed to be effectively implemented. Training may need to be adequately planned so all teachers can be able to acquire the necessary skills for a correct use of the new technology (Tyler-Wood, Cockerham and Johnson, 2018).

Regarding the incorporation of Holograms in children's education mentioned on previous researches, the students were interested in this kind of learning method compared to conventional teaching approaches. "They enjoyed it and requested to have this kind of technology as a learning method in the school. Likewise, all the teachers were 
also excited about the 3D hologram technology" (Hoon and Shaharuddin, 2019). "It is difficult to construct a three-dimensional image in free space allowing view from all directions or positions. From a mathematical point-of-view, the construction of 3D image in free space is a definite boundary solution problem of passive space" (Wang, 2017).

\section{Participants}

In Ecuador we could not find any studies of working with holograms and how they improve attention and motivate students' learning. Therefore, we chose the Klebér Franco Cruz school in the city of Machala to conduct a research by incorporating the resource 3D Holographic LED-Fan Display in a classroom of an educational institution. University students contributed to this research, since addressing educational and learning issues in education are part of a social problem. Hence, generate elements for their understanding, and strategies that allow theoretical-practical integration, fostering spaces between teachers and students are very important to measure developed potentialities which allow having a clear and professionally precise vision of education. During classroom observation practices in the Kléber Franco Cruz School, where students from the third level of the Experimental Sciences Pedagogy of the Technical University of Machala actively participated, allowing a work experience, thus by observing through the educational environment, they would imagine the challenges that future professionals face. The different shortcomings they faced were due to lack of interest from students to learn or fulfill their academic responsibility.

Student participation in class is a very important aspect. Hence the emphasis, as the author Chan states: "Collaboration and partnership are key components of systemic change improvement efforts should involve participation and support from people at multiple levels. Whilemacro-level policy and institutional changes may set the stage, wide gaps exist between educational policies, research findings, and the classroom" (Chan, 2011).

It should be noted that during the classroom observation process, the distraction of the students could be verified, either through the use of their mobile device or through dialogue with their class partners. Besides, it is important to highlight the lack of techno-pedagogical resources which produce a lack of interest in studying the subject of the class taught by the teacher. "The use of modern technology-oriented methodology for learning is a very attractive topic which provides the fundamental content of today's education. It also demonstrates an interesting view on what might be missing and added when technology is introduced into the educational process. The study considers higher education institutions as to where and how the curriculum needs be brought on the track that reflect the dynamic nature and commitment of students to the learning practice. This means that a new curriculum be designed, but assessment processes must reflect individual learning assessment; collaborative activity, appropriate technological involvement, and different approaches for identifying problems" (Ullah Jan, 2018).

Considering the different shortcomings that intervene in the teaching-learning process of the students, we have considered important to use the hologram tool as a techno-pedagogical resource since it allows viewing both normal images and advanced photographs, likewise it is possible to observe objects from a three-dimensional 
perspective. This resource will help the teacher to make their classes more dynamic and in turn will catch the interest of students to learn the subject that is being taught. According to that quoted by Thanga, (Thanga Shyla, 2015b) "The importance of teacher as an agent of change, promoting understanding and tolerance has never been more obvious than today. The need for change, from narrow nationalism to universalism, from ethic and cultural prejudice to tolerance, understanding and pluralism, from autocracy to democracy in its various manifestations, and from a technologically divided world where high technology is the privilege of the few to a technologically united world, places enormous responsibilities on teachers who participate in the molding of the characters and minds of the new generation".

It is therefore necessary to develop creative and innovative strategies which can be achieved by emphasizing learning. In this respect, teachers who have and transmit high expectations for their students are the role models to start developing new ways of teaching. The teachers who implement a variety of teaching strategies and work together to create life-related curriculum materials under a stimulating learning environment in which creativity, joy and self-esteem become the paths to reach academic excellence (Cabrales Salazar, 2017).

\section{Instruments}

A pre-questionnaire was carried out before the use of the pedagogical resource according to the traditional class of the teacher and a post-questionnaire after the demotivating class with application of holograms in the contents of the subject. The applied questionnaire was based on objective, single-choice questions. Third-year students were selected for their attitudes and predisposition to research work, as well as their teachers and authorities.

After the observation made by the students of the experimental class, the postquestionnaire was taken. The set of questions was based on examining: a) learning with technological resources, b) educational technology in the classes, c) interest and motivation in the classroom, d) improving learning by applying technopedagogical resources. The information was tabulated using the IBM SPSS statistical software version 22 .

\section{Methods}

The methodology applied to this research has a mixed approach framed in a case study enhanced at the secondary level of education. Applying a mixed methodology, an attempt is made to contribute to the objective of the research, as stated by other authors. This is important because, the research has a mixed approach, both qualitative and quantitative. Mixed methods offer not only "new tricks" for collecting and analyzing data; more importantly, they have the potential to foster theory building (Wu, 2012).

This approach facilitates the collection of information and the interpretation of results, since it is currently widely used as predicted in 2018 by Creswell and Garrett (Creswell and Garrett, 2008), there is a worldwide increased interest in mixed methods research, and it is likely to continue over the next few years. Like qualitative research, we believe that mixed methods are here to stay as a research approach. The resource used for holographic projection is 3D Holographic LED-Fan Display, and thanks to this 
device, it has never been so accessible to project images and videos with fabulous special effects, since it is designed for this purpose. View as reference Fig. 1.

Among the most important characteristics, it should be commented that 3D LEDFan it is easy to install and totally light, but also it is a fragile model and, therefore, must be kept at a distance.

The elements to take into account are the number of LED pieces that allow the projected images to be viewed and their resolution, their hours of useful life, the voltage used, energy saving, their angle of rotation, and finally is necessary to mention that it supports several formats of images. The specifications can be viewed in the Table 1.

The device needs a pendrive are to store the images to be projected on a hologram.

- 3D Holographic LED-Fan Display

- 3D images

- Nearpod application to evaluate content. (Optional)

After reviewing the contents, three-dimensional images were stored to be projected on the 3D Holographic LED-Fan Display, which will motivate students to learn the content to be taught Fig. 2.

The action research is a methodological strategy of educational research that consists of identifying persistent problems in the teaching-learning process, to suggest and disseminate strategies and alternative solutions which aimed at improving education. It seeks to develop in students an interdisciplinary and systematic approach to deal with concurrent problem situations in society, and in turn to select the educational approach that allows to apply an effective solution to the identified problem. In this work, the research line has been based on the diagnostic approach of case studies applied to educational technology.

\section{Results and discussion}

The pre-questionnaire and post-questionnaire was applied to students of the Kléber Franco Cruz School. A total of 30 students from the third course were selected. The context of the research was in the academic period carried out in the year 2019-2020.

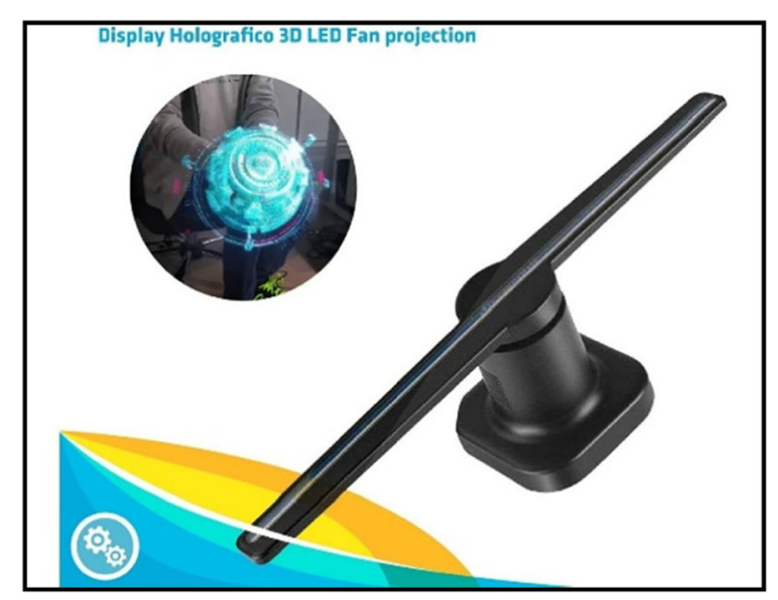

Fig. 1 3D Holographic LED-Fan Display Device 
Table 1 Holographic display elements

\begin{tabular}{|c|c|c|}
\hline Characteristic & Description & Components \\
\hline $\begin{array}{l}\text { Use the ultra-high density LED rotating } \\
\text { images to show } 3 D \text { visual effects of the } \\
\text { display device }\end{array}$ & Model: FY3D-Z1. & $\begin{array}{l}\text { Hologram projector - Used for the } \\
\text { projection of holographic images with } \\
\text { a realistic 3D appearance. }\end{array}$ \\
\hline $\begin{array}{l}\text { Product imaging clear, flexible } \\
\text { replacement of advertising content. }\end{array}$ & $\begin{array}{l}\text { Input Voltage: } 100-240 \mathrm{~V} \\
\text { AC } 50 / 60 \mathrm{~Hz}\end{array}$ & $\begin{array}{l}\text { Remote control - Electronic device that } \\
\text { allows us to take control of the device } \\
\text { (turn on / off). }\end{array}$ \\
\hline $\begin{array}{l}\text { Supports multiple online, so that the } \\
\text { playback screen is larger and clearer. }\end{array}$ & $\begin{array}{l}\text { Power: 10-15WLector de } \\
\text { Plug: US Plug, UK Plug, EU } \\
\text { Plug, AU Plug, JP Plug } \\
\text { Resolution (pixel): } 450 \times \\
224 \text {. }\end{array}$ & $\begin{array}{l}\text { Adapter } 12 \mathrm{v} \text { - It is equipped with a } \\
\text { fixed or adjustable voltage output; in } \\
\text { this way, the power supply devices can } \\
\text { limit the current voltage to a certain } \\
\text { extent so the test circuits are not } \\
\text { destroyed }\end{array}$ \\
\hline $\begin{array}{l}\text { It is very easy to carry, can be installed } \\
\text { by rotating or hanging on the wall to } \\
\text { install, will not occupy too much space. }\end{array}$ & $\begin{array}{l}\text { Viewing Angle: } 176^{\circ} \\
\text { File Formats supported: } \\
\text { MP4,AVI, RMVB,G IF, JPG, } \\
\text { MKV, PNG }\end{array}$ & $\begin{array}{l}\text { Color: Black/White } \\
\text { Material: ABS \& PC \& Aluminum } \\
\text { Item Size: Approx. } 42^{*} 13^{*} 11 \mathrm{~cm}\end{array}$ \\
\hline $\begin{array}{l}\text { Fantastic 3D video playback effect, you } \\
\text { can make your advertisement, and it's a } \\
\text { new product with a marketing eye- } \\
\text { catching potential }\end{array}$ & $\begin{array}{l}\text { LED Quantity: } 224 p c s \\
\text { LED Life: } 100000 \mathrm{~h}\end{array}$ & \\
\hline
\end{tabular}

The analysis indicates that we have a good number of Afro-descendant students with $33.3 \%$ of the total number of participants, and firstly the Mestizos with $40 \%$. Machala is a coastal city of Ecuador and there is a great influence of Afro-descendants. View Table 2 as reference.

When comparing the results on learning with and without technological devices in the classroom, students stated that the application of the holographic device in biology class was very interesting because they considered that it is more important to see an object than just imagine it as they expressed it $63.33 \%$ of the post-questionnaire versus $3.3 \%$ of pre-questionnaire. The majority of students who considered class boring (40\%) now find it very interesting. View Table 3 as reference.

In reference to the use of educational technology by the teacher in the classroom, students express there is a traditional model with a margin of $43.3 \%$ in the prequestionnaire, the opposite happens when applying 3D Holographic LED-Fan Display

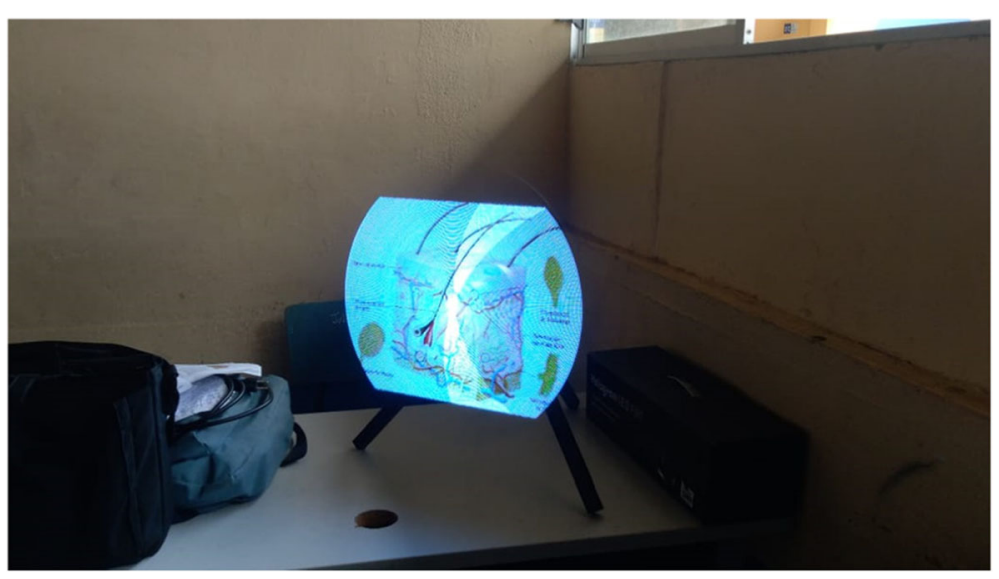

Fig. 2 Hologram showed in the classroom 
Table 2 Participants students, cross reference

\begin{tabular}{|c|c|c|c|c|c|}
\hline \multicolumn{6}{|c|}{ Gender: Female 15; Male: 15, Total 30} \\
\hline \multirow[t]{2}{*}{ Ethnicity } & & \multicolumn{3}{|c|}{ How old are you? } & \multirow[t]{2}{*}{ Total } \\
\hline & & 16 & 17 & 18 & \\
\hline \multirow[t]{2}{*}{ Mestizo } & recount & 9 & 2 & 1 & 12 \\
\hline & $\%$ of total & $30,0 \%$ & $6,7 \%$ & $3,3 \%$ & $40,0 \%$ \\
\hline \multirow[t]{2}{*}{ White } & recount & 1 & 1 & 0 & 2 \\
\hline & $\%$ of total & $3,3 \%$ & $3,3 \%$ & $0,0 \%$ & $6,7 \%$ \\
\hline \multirow[t]{2}{*}{ Afro-descendant } & recount & 5 & 3 & 2 & 10 \\
\hline & $\%$ of total & $16,7 \%$ & $10,0 \%$ & $6,7 \%$ & $33,3 \%$ \\
\hline \multirow[t]{2}{*}{ Montubio } & recount & 0 & 1 & 1 & 2 \\
\hline & $\%$ of total & $0,0 \%$ & $3,3 \%$ & $3,3 \%$ & $6,7 \%$ \\
\hline \multirow[t]{2}{*}{ Indigenous } & recount & 4 & 0 & 0 & 4 \\
\hline & $\%$ of total & $13,3 \%$ & $0,0 \%$ & $0,0 \%$ & $13,3 \%$ \\
\hline \multirow[t]{2}{*}{ Total } & Recuento & 19 & 7 & 4 & 30 \\
\hline & $\%$ del total & $63,3 \%$ & $23,3 \%$ & $13,3 \%$ & $100,0 \%$ \\
\hline
\end{tabular}

with the content of the subject increasing its attention to interesting by $33.3 \%$ and very interesting by $53.3 \%$, the results are optimistic. View Table 4 as reference.

Student participation in classes is a factor to measure their motivation and interest in the subject content. Some of the strategies and activities planned by the teacher make it interesting with $43.3 \%$ of acceptance in addition to $20 \%$ that they consider boring according to the pre-questionnaire at first instance. In a second moment, by incorporating 3D Holographic LED-Fan Display, it is logical to presume which facilitates attention and increased the curiosity and participation of students, improving their

Table 3 Comparative pre and post- questionnaire about learning with technological resources.

Cross reference

\begin{tabular}{|c|c|c|c|c|c|c|}
\hline \multicolumn{2}{|c|}{$\begin{array}{l}\text { Without recourses in } \\
\text { classroom }\end{array}$} & \multicolumn{5}{|c|}{$\begin{array}{l}\text { How do you consider your learning without the use of technology (projector, } \\
\text { device, computer) in biology class? }\end{array}$} \\
\hline & & Boring & Traditional & Interesting & Very interesting & Total \\
\hline \multirow[t]{2}{*}{ Male } & recount & 7 & 4 & 3 & 1 & 15 \\
\hline & $\%$ of total & $23,3 \%$ & $13,3 \%$ & $10,0 \%$ & $3,3 \%$ & $50,0 \%$ \\
\hline \multirow[t]{2}{*}{ Female } & recount & 5 & 4 & 6 & 0 & 15 \\
\hline & $\%$ of total & $16,7 \%$ & $13,3 \%$ & $20,0 \%$ & $0,0 \%$ & $50,0 \%$ \\
\hline \multirow[t]{2}{*}{ Total Students } & recount & 12 & 8 & 9 & 1 & 30 \\
\hline & $\%$ of total & $40,0 \%$ & $26,7 \%$ & $30,0 \%$ & $3,3 \%$ & $100,0 \%$ \\
\hline \multirow{2}{*}{\multicolumn{2}{|c|}{ With recourses in classroom }} & \multicolumn{5}{|c|}{$\begin{array}{l}\text { Do you think that I improve your learning with the use of technology (3D } \\
\text { Holographic LED-Fan Display) in biologyclass? }\end{array}$} \\
\hline & & Boring & Traditional & Interesting & Very interesting & Total \\
\hline \multirow[t]{2}{*}{ Male } & recount & 0 & 1 & 3 & 11 & 15 \\
\hline & $\%$ of total & $0 \%$ & $3,3 \%$ & $10,0 \%$ & $36,7 \%$ & $50,0 \%$ \\
\hline \multirow[t]{2}{*}{ Female } & recount & 0 & 1 & 6 & 8 & 15 \\
\hline & $\%$ of total & $0 \%$ & $3,3 \%$ & $20,0 \%$ & $26,7 \%$ & $50,0 \%$ \\
\hline \multirow[t]{2}{*}{ Total Students } & recount & 0 & 2 & 9 & 19 & 30 \\
\hline & $\%$ of total & $0 \%$ & $6,7 \%$ & $30,0 \%$ & $63,3 \%$ & $100,0 \%$ \\
\hline
\end{tabular}


Table 4 Comparative pre and post- questionnaire about educative technology in class. Cross reference

\begin{tabular}{|c|c|c|c|c|c|c|}
\hline \multicolumn{2}{|c|}{$\begin{array}{l}\text { Without educative } \\
\text { technology }\end{array}$} & \multicolumn{5}{|c|}{$\begin{array}{l}\text { Would you like technology educative to be used for the development of the } \\
\text { class? }\end{array}$} \\
\hline & & Boring & Traditional & Interesting & Very interesting & Total \\
\hline \multirow[t]{2}{*}{ Male } & recount & 4 & 7 & 3 & 1 & 15 \\
\hline & $\%$ of total & $13,3 \%$ & $23,3 \%$ & $10,0 \%$ & $3,3 \%$ & $50,0 \%$ \\
\hline \multirow[t]{2}{*}{ Female } & recount & 1 & 6 & 8 & 0 & 15 \\
\hline & $\%$ of total & $3,3 \%$ & $20,0 \%$ & $26,7 \%$ & $0,0 \%$ & $50,0 \%$ \\
\hline \multirow[t]{2}{*}{ Total Students } & recount & 5 & 13 & 11 & 1 & 30 \\
\hline & $\%$ of total & $16,7 \%$ & $43,3 \%$ & $36,7 \%$ & $3,3 \%$ & $100,0 \%$ \\
\hline \multirow{2}{*}{\multicolumn{2}{|c|}{ With educative technology }} & \multicolumn{5}{|c|}{$\begin{array}{l}\text { Did you like to use technology educative (3D Holographic LED-Fan Display) in the } \\
\text { developpment of the class? }\end{array}$} \\
\hline & & Boring & Traditional & Interesting & Very interesting & Total \\
\hline \multirow[t]{2}{*}{ Male } & recount & 0 & 2 & 6 & 7 & 15 \\
\hline & $\%$ of total & $0,0 \%$ & $6,7 \%$ & $20,0 \%$ & $23,3 \%$ & $50,0 \%$ \\
\hline \multirow[t]{2}{*}{ Female } & recount & 1 & 1 & 4 & 9 & 15 \\
\hline & $\%$ of total & $3,3 \%$ & $3,3 \%$ & $13,3 \%$ & $30,0 \%$ & $50,0 \%$ \\
\hline \multirow[t]{2}{*}{ Total } & recount & 1 & 3 & 10 & 16 & 30 \\
\hline & $\%$ of total & $3,3 \%$ & $10,0 \%$ & $33,3 \%$ & $53,3 \%$ & $100,0 \%$ \\
\hline
\end{tabular}

willingness to learn individually and collectively. This was considered very interesting for $60 \%$ of the participants. View Table 5 as reference.

The students showed a greater degree of interest in viewing the hologram depicting about the sense organs in biology class. In the pre-questionnaire they found the images of their textbook interesting with $46.7 \%$. According to the results, there is a great difference between the traditional and the boredom method which dropped considerably to

Table 5 Comparative pre and post- questionnaire about interest and motivation in the classroom. Cross reference

\begin{tabular}{|c|c|c|c|c|c|c|}
\hline \multicolumn{2}{|c|}{$\begin{array}{l}\text { Without resource } \\
\text { technological }\end{array}$} & \multicolumn{5}{|c|}{$\begin{array}{l}\text { Does the content of the subject seem interesting and motivates you to participate } \\
\text { in class? }\end{array}$} \\
\hline & & Boring & Traditional & Interesting & Very interesting & Total \\
\hline \multirow[t]{2}{*}{ Male } & recount & 5 & 4 & 5 & 1 & 15 \\
\hline & $\%$ of total & $16,7 \%$ & $13,3 \%$ & $16,7 \%$ & $3,3 \%$ & $50,0 \%$ \\
\hline \multirow[t]{2}{*}{ Female } & recount & 1 & 0 & 8 & 6 & 15 \\
\hline & $\%$ of total & $3,3 \%$ & $0,0 \%$ & $26,7 \%$ & $20,0 \%$ & $50,0 \%$ \\
\hline \multirow[t]{2}{*}{ Total } & recount & 6 & 4 & 13 & 7 & 30 \\
\hline & $\%$ of total & $20,0 \%$ & $13,3 \%$ & $43,3 \%$ & $23,3 \%$ & $100,0 \%$ \\
\hline \multirow{2}{*}{\multicolumn{2}{|c|}{$\begin{array}{l}\text { With resource } \\
\text { technological }\end{array}$}} & \multicolumn{5}{|c|}{$\begin{array}{l}\text { Did you find it interesting to assign a hologram to the content of the subject and } \\
\text { was you motivated to participate in class? }\end{array}$} \\
\hline & & Boring & Traditional & Interesting & Very interesting & Total \\
\hline \multirow[t]{2}{*}{ Male } & recount & 0 & 3 & 4 & 8 & 15 \\
\hline & $\%$ of total & $0,0 \%$ & $10,0 \%$ & $13,3 \%$ & $26,7 \%$ & $50,0 \%$ \\
\hline \multirow[t]{2}{*}{ Female } & recount & 2 & 1 & 2 & 10 & 15 \\
\hline & $\%$ of total & $6,7 \%$ & $3,3 \%$ & $6,7 \%$ & $33,3 \%$ & $50,0 \%$ \\
\hline \multirow[t]{2}{*}{ Total } & recount & 2 & 4 & 6 & 18 & 30 \\
\hline & $\%$ of total & $6,7 \%$ & $13,3 \%$ & $20,0 \%$ & $60,0 \%$ & $100,0 \%$ \\
\hline
\end{tabular}


increase the option "very interesting" in the post-questionnaire thus its percentage grew to $63.3 \%$. View Table 6 as reference.

The implementation was completed thanks to the previous acquisition of the UTMACH student practitioners of the 3D Holographic LED-Fan's Display with their own funds and before carrying out pre-professional practices at the School.

Once they chose their theme for the knowledge integration project, they established four phases that were given in the classroom each time the Third Baccalaureate Course corresponded to them according to their schedule. View Table 7 as reference.

For the final evaluation of what was learned, the Nearpod tool was used. Many of the topics were correctly answered by the students.

\section{Study limitations and recommendations}

Acquiring a 3D Holographic LED-Fan Display is somehow difficult in Ecuador because is a limited which needs to be imported. But through the Web it is easy to buy, thus the university students acquired with their own funds to carry out this research and promote its use in classrooms. The motivation they had was to contribute to the promotion and use of new technologies that help to improve the interest of teachers and students and enhance the classroom environment with the active participation and interaction of all its actors.

Some recommendations are suggested such as:

- Insist on the reinforcement of student's values that help in the formation of their daily and academic life by allowing to develop a mutual respect between teacherstudent.

Table 6 Comparative pre and post- questionnaire about improving learning by applying technopedagogical. Cross reference

\begin{tabular}{|c|c|c|c|c|c|c|}
\hline \multicolumn{2}{|c|}{$\begin{array}{l}\text { Without 3D Led Fan } \\
\text { Hologram }\end{array}$} & \multicolumn{5}{|c|}{$\begin{array}{l}\text { Would it facilitate your learning and interest in the subject when viewing hologram } \\
\text { as part of your class activities? }\end{array}$} \\
\hline & & Boring & Traditional & Interesting & Very interesting & Total \\
\hline \multirow[t]{2}{*}{ Male } & recount & 1 & 3 & 8 & 3 & 15 \\
\hline & $\%$ of total & $3,3 \%$ & $10,0 \%$ & $26,7 \%$ & $10,0 \%$ & $50,0 \%$ \\
\hline \multirow[t]{2}{*}{ Female } & recount & 2 & 5 & 6 & 2 & 15 \\
\hline & $\%$ of total & $6,7 \%$ & $16,7 \%$ & $20,0 \%$ & $6,7 \%$ & $50,0 \%$ \\
\hline \multirow[t]{2}{*}{ Total } & recount & 3 & 8 & 14 & 5 & 30 \\
\hline & $\%$ of total & $10,0 \%$ & $26,7 \%$ & $46,7 \%$ & $16,7 \%$ & $100,0 \%$ \\
\hline \multirow{2}{*}{\multicolumn{2}{|c|}{$\begin{array}{l}\text { With 3D Led Fan } \\
\text { Hologram }\end{array}$}} & \multicolumn{5}{|c|}{$\begin{array}{l}\text { Did I improve your interest in the contents of the class by incorporating holograms } \\
\text { as a techno-pedagogical resource? }\end{array}$} \\
\hline & & Boring & Traditional & Interesting & Very interesting & Total \\
\hline \multirow[t]{2}{*}{ Male } & recount & 0 & 0 & 5 & 10 & 15 \\
\hline & $\%$ of total & $0,0 \%$ & $0,0 \%$ & $16,7 \%$ & $33,3 \%$ & $50,0 \%$ \\
\hline \multirow[t]{2}{*}{ Female } & recount & 1 & 1 & 4 & 9 & 15 \\
\hline & $\%$ of total & $3,3 \%$ & $3,3 \%$ & $13,3 \%$ & $30,0 \%$ & $50,0 \%$ \\
\hline \multirow[t]{2}{*}{ Total } & recount & 1 & 1 & 9 & 19 & 30 \\
\hline & $\%$ of total & $3,3 \%$ & $3,3 \%$ & $30,0 \%$ & $63,3 \%$ & $100,0 \%$ \\
\hline
\end{tabular}


Table 7 Phases of experimental class of biology

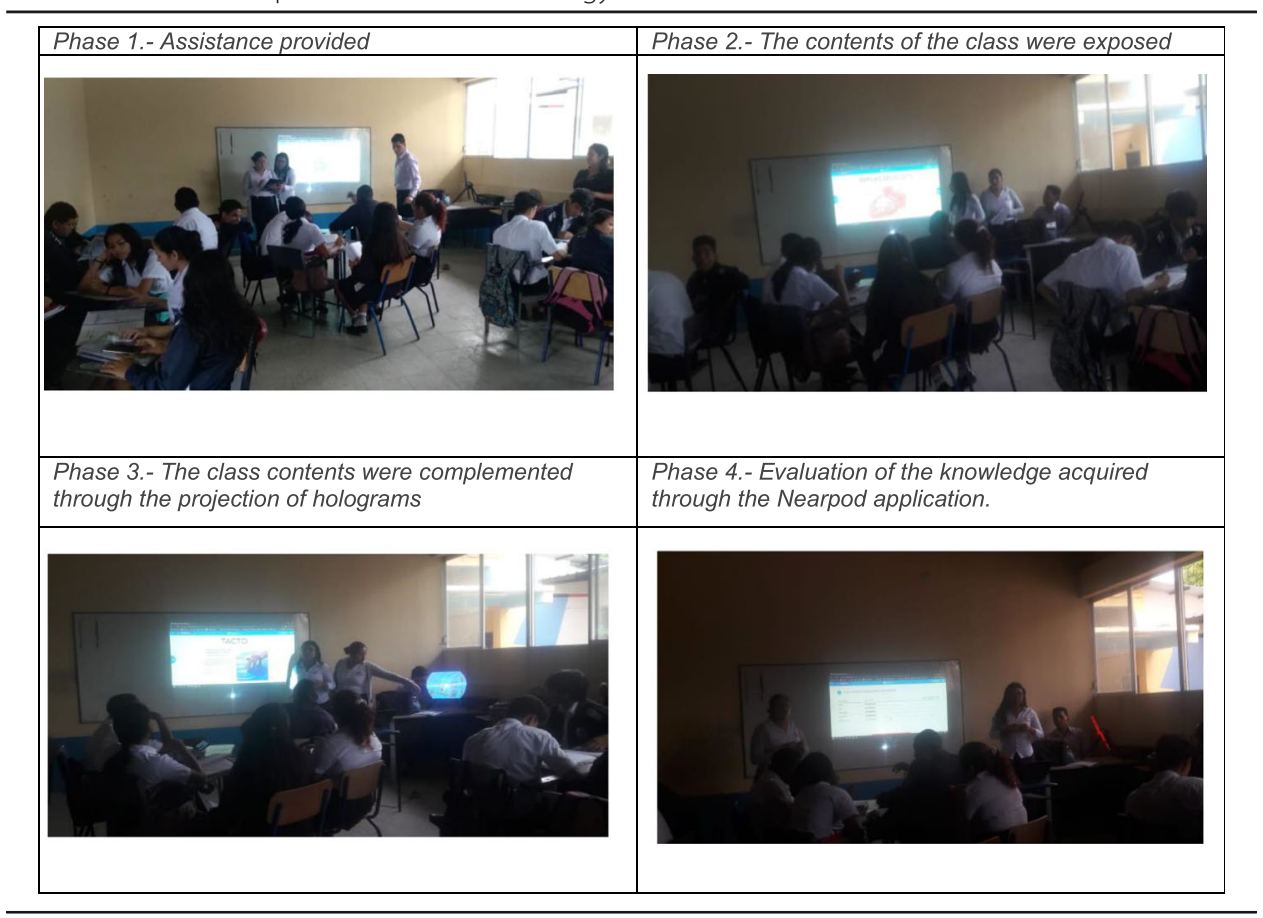

- For students, it's necessary to know how making a good use of new technologies, more specifically, the use of 3D Holographic LED-Fan Display.

- Adopt educational technologies which can help to improve students' interest.

\section{Conclusion}

In accordance with the general objective, it has been necessary to promote the use of the 3D Holographic LED-Fan Display in the classroom as a techno-pedagogical resource, determining its effect would effectively strengthen the dynamics of the classes, especially in the subject of biology chosen in the Third Baccalaureate of the Kléber Franco Cruz School, with the guidance and supervision of one of the Institution's teachers. By integrating the use of educational technology in the classroom with Holographic Display and the Nearpod application will significantly encourage students' participation during the class development. In addition, the benefits and contributions to the teaching-learning process are they were very important because it was something new, attractive and technological.

- Through the observation practices in the classroom and according to the comparison between the results of the applied surveys, it is shown how the academic interest of the students can progressively improve by incorporating the use of the techno-pedagogical resource in harmony with the contents that the teacher wants to teach. The success achieved through the application of holograms is to attract the student's attention and avoid being entertained by other ideas.

- Among the results achieved, through the incorporation of 3D Holographic LEDFan Display during the development of experimental classes, it can be established teachers can easily manipulate the resource and interact in real time with their 
students, thus significantly improving their participation and interest in the topics and contents.

- In order to assess the knowledge of secondary students, an exam was applied to the contents of the experimental classes, which were carried out with the help of an alternative computer tool called Nearpod, which was provided by university students. The average of the students was high above the standard (from 1 to 10) by obtaining grades over 7 points.

By interacting with the techno-pedagogical resource, a greater interest in students' learning is evident, due to this different, modern and new way of carrying out the development of the class. Also, the interaction with Nearpod provides the activities with a meaningful learning in real-time. Besides, the Holographic Display arises a big curiosity among students when observing the three-dimensional images, which leads to the feeling of perceiving the objects.

In conclusion, the use of these tools will definitely contribute to the improving of the development of meaningful learning in the current education context.

\section{Abbreviation}

UTMACH: Technical University of Machala; 3D: Three-dimensional

\section{Acknowledgements}

We express our sincere thanks in the first place to Ab. Efren Espinoza Aguilar, Rector of the Kléber Franco Cruz School, for the provided support. To Educational District of Machala that maintains the current agreements for pre-professional practices with the students of Technical University of Machala. To Ing. Rossemary Samaniego Ocampo, Dean of our Faculty of Social Sciences and to Ing. Amarilis Borja Herrera, Academic Vice-Rector of the Technical University of Machala. We also thank the students Thalia Giron, Soraya Queada, Steven Armijos, Janeth Cujilema, Liseth Samaniego, Jennifer Pizarro.

\section{Authors' contributions}

Prado Mauricio, is the leader of the research on an integrated project of knowledge in the field of PedagogyExperimental Sciences and takes part of the pre-professional practices of his university students in secondary education. Valarezo Jorge, responsible for the application of the integrated project's knowledge in secondary education institutions. Delgado Jorge, responsible for analyzing the research data. Armijos Jorge, responsible for interpreting the results of the investigation. Ávila Asisclo, responsible for statistical tables and graphs in IBM SpsS Software used during the research. Gónzalez Anyeline, responsible for coordinating the research with the students of the Kléber Franco Cruz School. The author(s) read and approved the final manuscript.

\section{Authors' information}

Prado Ortega Mauricio Xavier, is an Occasional Professor at the Technical University of Machala for many years. He currently works at the Faculty of Social Sciences and teaches theoretical and research subjects to his students. He obtained his Master's Degree in Health Management for Local Development at the Private University of Loja and another Master's Degree at the University of Guayaquil. He was the Manager of the Financial Department of the IESS General Hospital of Machala in 2015 for almost two years and an Accountant for more than 6 years since 2010.

Delgado Ramírez Jorge Cristopher, is a Professor at the Technical University of Machala for two years. He currently works at the Faculty of Social Sciences and teaches theoretical and educational technology subjects to his students. He obtained his Master's in Technology and Educational Innovation at the Casa Grande University in the city of Guayaquil.

Valarezo Castro Jorge Washington, has been a Professor at the Technical University of Machala for many years. He currently works at the Faculty of Social Sciences and teaches theoretical and educational technology subjects to his students. He obtained his Master's Degree in Teaching and Management of Higher Education at the University of Guayaquil. He was a teacher at the Ismael Pérez Pazmiño Institute for about 6 years.

Armijos Carrión Jorge Luis, is a Professor at the Technical University of Machala for two years. He currently works at the Faculty of Social Sciences and teaches theoretical and educational technology subjects to his students. He obtained his Master's Degree in Teaching and Management in Higher Education at the University of Guayaquil. 
González Segarra Anyeline Natalia, is a Teacher at the Klebér Franco Cruz School in the city of Machala for three consecutive years. She is currently pursuing a Master's of Education with specialization in Pedagogy at the Universidad Tecnológica Empresarial de Guayaquil.

Funding

Not applicable.

\section{Availability of data and materials}

Not applicable.

\section{Competing interests}

The authors declare they have no competing interests.

\section{Author details}

${ }^{1}$ Universidad Técnica de Machala, Avenida Panamericana km 5.5 via a Pasaje, Machala, Ecuador. ${ }^{2}$ Universidad Técnica de Machala, Machala, Ecuador. ${ }^{3}$ Colegio Klebér Franco Cruz, Avenida 25 de junio y carrera 11 ava oeste 614, Machala, Ecuador.

Received: 11 May 2020 Accepted: 3 September 2020

Published online: 20 October 2020

\section{References}

Cabrales Salazar, O. (2017). Playing and creativity as pedagogical strategies to face the new challenges of education in Colombia. Science Journal of Education, 5(6), 244. https://doi.org/10.11648/j.sjedu.20170506.13.

Chan, C. K. K. (2011). Bridging research and practice: Implementing and sustaining knowledge building in Hong Kong classrooms. Inernational Journal of Computer Collaborative Learning, 6(2), 147-186. https://doi.org/10.1007/s11412-0119121-0.

Creswell, J. W., \& Garrett, A. L. (2008). The 'movement' of mixed methods research and the role of educators. South African Journal of Education, 28(3), 321-333. https://doi.org/10.15700/saje.v28n3a176.

Falloon, G. (2020). From digital literacy to digital competence: the teacher digital competency (TDC) framework. Educational Technology Research and Development, 1-24. https://doi.org/10.1007/s11423-020-09767-4

Givan, C. (2018). What is a virtual world? Definition and classification. Educational Technology Research and Development, 66(5), 1087-1100. https://doi.org/10.1007/s11423-018-9577-y.

Hayaati, N., Alwi, M., \& Wahab, H. A. (2017). A holographic viewer in mobile devices to increase learning experience. In Proc. Int. Univ. CARNIVAL e-LEARNING, (pp. 352-353) [En línea]. Disponible en: http://creativecommons.org/licences/by-sa/4.0 http://goal-itqan.usim.edu.my/.

Hoon, L. N., \& Shaharuddin, S. S. (2019). Learning effectiveness of 3D hologram animation on primary school learners. Journal of Visual Art and Design, 11(2), 93-104. https://doi.org/10.5614/j.vad.2019.11.2.2.

Mora Rodríguez, R. (2013). Implementation process of technology in Education: the case of Blackboard 9.1 in the University of Manchester. Actualidades Investigativas en Educación, 13(3). https://doi.org/10.15517/aie.v13i3.12043.

C. R. Ramachandiran, M. M. Chong, y P. Subramanian, "3D Hologram in futuristic classroom: a review", Periodicals of Engineering and Natural Sciences, vol. 7 2, pp. 580-586, 2019, doi: https://doi.org/10.21533/pen.v7i2.441.

Thanga Shyla, S. D. (2015a). Enriching and enhancing life skills by learning science among adolescents. Science Journal of Education, 3(4), 21. https://doi.org/10.11648/j.sjedu.s.2015030401.15.

Thanga Shyla, S. D. (2015b). Impact of formative assessment: comparative analysis on the performance of Bachelor of Science in Education Students. Science Journal of Education, 3(4), 5. https://doi.org/10.11648/j.sjedu.s.2015030401.12.

Tyler-Wood, T. L., Cockerham, D., \& Johnson, K. R. (2018). Implementing new technologies in a middle school curriculum: a rural perspective. Smart Learning Environments, 5(1), 22. https://doi.org/10.1186/s40561-018-0073-y.

Ullah Jan, S. (2018). Education in the age of technology: contrasting fortunes. Science Journal of Education, 6(2), 55. https://doi. org/10.11648/j.sjedu.20180602.13.

Wang, G. (2017). Field reconstruction of holograms for interactive free space true three dimensional display. World Journal of Applied Physics, 4(3), 41. https://doi.org/10.11648/j.wjap.20190403.12.

Wong, L. H., et al. (2020). IDC theory: interest and the interest loop. Research and Practice in Technology Enhanced Learning, 15(1), 3. https://doi.org/10.1186/s41039-020-0123-2.

Wu, P. F. (2012). A mixed methods approach to technology acceptance research. Journal of the Association for Information Systems, 13(3), 172-187. https://doi.org/10.17705/1jais.00287.

S. Yamada, T. Kakue, T. Shimobaba, y T. Ito, "Interactive holographic display based on finger gestures", Scientific Reports, vol. 8 1, 2018, doi: https://doi.org/10.1038/s41598-018-20454-6.

\section{Publisher's Note}

Springer Nature remains neutral with regard to jurisdictional claims in published maps and institutional affiliations. 